\title{
CELEBRATION COMMENTS
}

Health SA Gesondheid is celebrating its tenth birthday. Initially only nursing research and overview articles were published in this journal. The editorial board consisted mainly of nurses. Over the past ten years this has changed. The editorial board now consists of nurses, psychologists, a medical practitioner, a sport-and biokineticist and a social worker. The articles that are published in this journal now come from a variety of disciplines in the health science and human science fields. It has been accredited by the Department of Education. We are endeavouring to get it ISI rated.

Health SA Gesondheid's editorial board members have started with a tradition of conducting an annual workshop for authors and reviewers on the publishing of articles and what exactly the specific criteria are for getting an acceptable article published. These workshops will be alternated at different university campuses. We have built up a record of being rigorous in accepting articles for evaluation. We strive to be invitational in our feedback to budding authors. Excellence and quality are our main cornerstones.

On a more personal note our managing editor Liselle Viljoen and her husband have been blessed with a beautiful baby girl in January. May she experience the same prosperity as Health SA Gesondheid and continue to blossom.

Marie Poggenpoel, RN, Ph.D, L.Akad

Professor: Nursing Science

Professional editor

\section{VIERINGS KOMMENTAAR}

Health SA Gesondheid vier ' $n$ tiende verjaarsdag. Aanvanklik is slegs verpleegkundige navorsings-en oorsigsartikels gepubliseer in hierdie tydskrif. Die redaksionele komitee was hoofsaaklik saamgestel uit verpleegkundiges. Dit het egter oor die laaste tien jaar verander. Die raad bestaan nou uit verpleegkundiges, sielkundiges, 'n mediese praktisyn, ' $n$ sport-en biokinetikus en ' $n$ maatskaplike werker. Die artikels wat tans in hierdie tydskrif gepubliseer word kom van ' $n$ verskeidenheid dissiplines in die gesondheids-en menslike wetenskappe. Die tydskrif is geakkrediteer deur die Departement van Onderwys en ons poog om dit ISI geëvalueer te kry.

Health SA Gesondheid se redaksionele komitee het ' $n$ tradisie geloots om jaarliks ' $n$ werkswinkel aan te bied vir skrywers en evalueerders oor hoe om suksesvol in die tydskrif te publiseer sowel as kriteria vir ' $n$ aanvaarbare artikel om gepubliseer te word. Dié werkswinkels sal afgewissel word by verskillende universiteitskampusse. Ons het 'n rekord opgebou om streng te wees met die aanvaarding van artikels vir publikasie. Ons streef ook om uitnodigend te wees in ons terugvoering aan voornemende skrywers. Uitnemendheid en kwalititeit is die hoekstene waarop ons bou.

Op ' $n$ meer persoonlike trant wil ons net meedeel dat ons besturende redakteur Liselle Viljoen en haar eggenoot geseën is deur die geboorte van 'n pragtige dogter in Januarie. Ons wens haar alle voorspoed toe en hoop dat sy sal blom net soos Health SA Gesondheid.

Marie Poggenpoel, GV, D.Phil, L.Akad

Professor Verpleegkunde

Professionele redakteur 